COMRADES AND CRITICS:

WOMEN, LITERATURE, AND THE LEFT IN 1930 S CANADA 
This page intentionally left blank 
CANDIDA RIFKIND

\section{Comrades and Critics}

Women, Literature, and the Left in 1930s Canada 
(C) University of Toronto Press Incorporated 2009

Toronto Buffalo London

www.utppublishing.com

Printed in Canada

ISBN 978-0-8020-9267-0

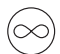

Printed on acid-free paper

\section{Library and Archives Canada Cataloguing in Publication}

Rifkind, Candida, 1972-

Comrades and critics: women, literature and the Left in 1930's Canada /

Candida Rifkind.

Includes bibliographical references and index.

ISBN 978-0-8020-9267-0

1. Authors, Canadian - 20th century - Political and social views. 2. Socialism and literature - Canada - History - 20th century. 3. Right and left (Political science) in literature. 4. Modernism (Literature) - Canada. 5. Canadian literature (English) - Women authors - History and criticism. 6. Canadian literature (English) - 20th century - History and criticism. 7. Nineteen thirties. I. Title.

University of Toronto Press acknowledges the financial assistance to its publishing program of the Canada Council for the Arts and the Ontario Arts Council.

This book has been published with the help of a grant from the Canadian Federation for the Humanities and Social Sciences, through the Aid to Scholarly Publications Programme, using funds provided by the Social Sciences and Humanities Research Council of Canada.

University of Toronto Press acknowledges the financial support for its publishing activities of the Government of Canada through the Book Publishing Industry Development Program (BPIDP). 